\title{
PENJADWALAN MATA KULIAH MENGGUNAKAN PEWARNAAN GRAF DENGAN ALGORITMA LARGEST FIRST
}

\author{
Andi P. Rahadi \\ Universitas Advent Indonesia \\ andi.rahadi@unai.edu
}

\begin{abstract}
Abstrak : Penjadwalan mata kuliah di universitas merupakan masalah multivariabel yang kompleks karena melibatkan banyak variabel yang memiliki keterbatasan yaitu banyak ruang kelas, jam kuliah, jadwal dosen, hingga jadwal mahasiswa yang akan berkuliah. Selama lebih dari 40 tahun masalah tersebut telah diteliti untuk diperoleh solusi optimal atau setidaknya mendekati optimal. Tujuan penelitian-penelitian itu adalah menghindari adanya bentrok antara variabel-variabel yang terlibat di dalam penjadwalan, dengan menggunakan model, pendekatan, metode, hingga membangun program komputer. Pewarnaan graf merupakan model yang paling banyak digunakan untuk memodelkan dan menyelesaikan masalah penjadwalan mata kuliah. Tulisan ini merupakan studi literatur mengenai beberapa algoritma pewarnaan graf dengan skema largest first yaitu algoritma Greedy dan algoritma Welsh-Powell yang digunakan untuk memodelkan dan menyelesaikan masalah penjadwalan matakuliah. Dengan memahami berbagai algoritma tersebut, diharapkan dapat dibentuk suatu model dan solusi yang sesuai untuk masalah penyusunan jadwal mata kuliah di universitas, khususnya di Indonesia.
\end{abstract}

Kata Kunci : Pewarnaan Graf, Penjadwalan Mata Kuliah, Greedy, Welsh Powell.

Abstract: Scheduling courses at university is a multivariable problem that is complex because it involves many variables that have limitations, e.g. the classrooms, lecture hours, lecturer schedules, and the schedule of students who will take the course. For more than 40 years the problem has been examined to obtain an optimal solution or at least close to optimal. The purpose of these studies is to avoid clashes between variables involved in the scheduling. Some research focus on developing model and/or approaches, and the other focus on building a computer program. Graph coloring is the most widely used model for modeling and resolving courses scheduling problems. This paper is a literature study on several graph coloring algorithms with the largest first scheme, i.e. the Greedy algorithm and the Welsh-Powell algorithm that are used to model and solve scheduling problems in the university course. By understanding these various algorithms, it is expected that a model and solution can be formed that is suitable for the problem of scheduling courses at universities, especially in Indonesia.

Keywords : Graph Coloring, Course Scheduling, Greedy, Welsh Powell.

\section{PENDAHULUAN}

Masalah penjadwalan mata kuliah di universitas merupakan salah satu tantangan sulit yang dihadapi oleh perguruan tinggi saat ini. Masalah tersebut bisa didefinisikan sebagai alokasi sumber daya yang diberikan (dosen, mahasiswa, dan ruang kelas) kepada objek (matakuliah) yang akan ditempatkan pada suatu slot waktu tertentu sedemikian hingga memenuhi semua kendala dan mengoptimalkan pemanfaatan fasilitas universitas yang ada, sehingga seperangkat tujuan yang diinginkan terpenuhi. Pada dasarnya, masalah jadwal universitas ada dalam dua bentuk yaitu, jadwal matakuliah dan jadwal ujian. Tulisan ini berfokus hanya pada masalah penjadwalan matakuliah. 
Masalah penjadwalan matakuliah pada umumnya merupakan masalah berskala besar sebab melibatkan ratusan hingga ribuan mahasiswa. Akibatnya penyelesaian masalah ini secara konvensional (manual ataupun menggunakan program komputer standar kantor) memerlukan waktu yang lama dan mengandung resiko bentrok jadwal yang cukup tinggi (Chauduri \& De, 2010). Bentrok jadwal dapat muncul akibat kesamaan dosen pengampu, kesamaan mahasiswa peserta, ataupun kesamaan ruangan antara dua atau lebih matakuliah. Oleh karena itulah masalah penjadwalan matakuliah ini menarik minat banyak peneliti sejak lebih dari 30 tahun yang lalu (Werra, 1984) hingga saat ini.

Jadwal matakuliah universitas dapat dibedakan menjadi beberapa kategori, yaitu kuliah, tutorial dan praktikum. Jadwal tersebut dilaksanakan secara mingguan dan diulang hingga suatu semester berakhir. Setiap mata kuliah memiliki jumlah mahasiswa terdaftar yang berbeda dan masing-masing ruang kelas memiliki kapasitas yang berbeda yang membuat penyusunan jadwal matakuliah menjadi cukup rumit. Selain menghindari bentrok jadwal, penjadwalan matakuliah sedapat mungkin harus meminumkan selisih antara kapasitas ruang kelas dengan banyaknya mahasiswa yang menjadi peserta kuliah di ruang tersebut. Otomatisasi masalah jadwal diperlukan agar dapat memberikan penghematan jam kerja institusi dan memberikan solusi optimal yang memenuhi setiap kendala, dengan demikian produktivitas meningkat serta kualitas pendidikan dan pelayanan menjadi prima.

Di antara berbagai usaha untuk memberikan solusi yang baik terhadap masalah penjadwalan matakuliah, pewarnaan graf merupakan pendekatan yang paling banyak digunakan. Burke menggunakan pendekatan graf heuristik pada papernya pada tahun 2003 (Burke, 2002), kemudian di tahun 2010 Chaudurin dkk mengembangkan pendekatan heuristik tersebut dengan konsep Fuzzy Genetik. Stevens (Stevens, 2005) menggunakan algoritma Greedy, dilengkapi bukti-bukti teorema yang terkait. Di Indonesia pun teknik pewarnaan graf untuk penjadwalan matakuliah juga menarik minat beberapa peneliti, dengan berbagai algoritma yang berbeda. Astuti (Astuti, 2011) menggunakan algoritma Welsh-Powell, sedangkan Ariani dkk (Ariani, 2011) menggunakan Particle Swarm Optimization, dan Setiawan (Setiawan, 2015) menggunakan algoritma kunang-kunang.

Dalam tulisan ini akan dipaparkan intisari algoritma pewarnaan graf berskema largest first, artinya simpul berderajat tinggi diwarnai telebih dahulu. Algoritma Greedy dan algoritma Welsh Powell akan dibahas secara runut pada subbab berikut, dimulai dari pengertian, urutan kerja, hingga contoh penerapannya pada penjadwalan matakuliah. Untuk mempercepat proses pembentukan graf, digunakan platform graf dari situs www.graphonline.ru, diakses pada tanggal 31 Desember 2018. 


\section{TUJUAN PENELITIAN}

Tulisan ini bertujuan menjawab pertanyaan-pertanyaan berikut

1. Bagaimana cara memodelkan masalah penjadwalan matakuliah menjadi graf?

2. Apa kesamaan dan perbedaan algoritma-algoritma pewarnaan graf berskema Largest First yang digunakan dalam penjadwalan matakuliah, khususnya Greedy dan Welsh-Powell?

3. Apa manfaat penggunaan graf online dalam pemodelan penjadwalan matakuliah?

\section{PEMBAHASAN}

\section{Pengenalan Graf}

Graf dalam cabang ilmu matematika kombinatorik berbeda dengan grafik dalam cabang ilmu kalkulus. Grafik merupakan penyajian geometrik dari suatu fungsi, sedangkan graf merupakan struktur diskrit yang terdiri dari simpul-simpul (vertices) dan sisi-sisi (edges) yang menghubungkan simpul-simpul tersebut (Rosen, 2012). Himpunan dari semua simpul anggota G dilambangkan dengan $V(G)$ sedangkan himpunan semua sisi anggota $\mathrm{G}$ dilambangkan dengan $E(G)$.

Teori Graf diperkenalkan oleh Leonhard Euler pada tahun 1735 untuk menyelesaikan masalah jembatan Konigsberg (Euler, 1741) . Dalam perkembangannya saat ini, teori graf diterapkan dalam beraneka bidang, mulai dari kimia, ekologi, genetika, olahraga, transportasi, pemetaan, jaringan komputer, dan sebagainya.

Dalam tulisan ini graf yang dibicarakan adalah graf sederhana tak berarah, yaitu graf yang tidak memiliki sisi rangkap dan setiap sisi tidak memiliki arah. Berikut ini dipaparkan beberapa pengertian dasar pada graf sederhana.

1. Dua simpul $u$ dan $v$ pada graf $G$ dikatakan adjacent bila ada sisi yang menghubungkan dua simpul tersebut, namakan sisi $e$. Dalam hal ini $e$ dikatakan incident pada $u$ maupun $v$.

2. Derajat dari suatu simpul $v$ menunjukkan banyaknya sisi yang incident dengan suatu vertex $v$ dan dilambangkan dengan $\operatorname{deg}(v)$. Nilai terbesar dari $\operatorname{deg}(v)$ memegang peranan penting dalam pewarnaan graf, dilambangkan $\Delta$,

$$
\max _{v \in V(G)} \operatorname{deg}(v)=\Delta .
$$

3. Graf $\mathrm{G}$ dengan $n$ buah simpul dikatakan lengkap (complete graf) bila setiap simpulnya saling adjacent, dengan demikian derajat setiap simpul sama besar, yaitu

$$
\operatorname{deg}(v)=n-1, \forall v \in V(G)
$$

4. Sebuah path dengan panjang $n$ dari simpul $u$ ke simpul $v$ di graf G adalah barisan $n$ buah simpul $x_{0}=u, x_{1}, \ldots, v=x_{n}$ di mana setiap simpul berurutan saling adjacent. Dalam hal 
$u=v$, path tersebut dinamakan circuit. Baik path maupun circuit dikatakan sederhana (simple path atau simple circuit) bila tidak memuat sisi yang sama lebih dari satu kali.

5. Graf $\mathrm{G}$ dikatakan terhubung (connected) bila ada path di antara setiap dua simpul berbeda di G.

6. Graf $\mathrm{G}$ dikatakan reguler bila setiap simpulnya memiliki derajat yang sama, bila tidak demikian graf G dikatakan non-reguler. Suatu graf reguler dengan derajat setiap simpulnya $\mathrm{k}$, dinamakan k-reguler graf.

7. Subgraf dari $V(G)$ dengan sifat setiap 2 simpulnya saling adjacent disebut dengan clique, dengan kata lain clique merupakan subgraf yang bersifat lengkap. Bila clique tersebut terdiri dari $\mathrm{k}$ buah simpul maka dikatakan clique tersebut berukuran $\mathrm{k}$.

\section{Pewarnaan Graf}

Ada tiga jenis pewarnaan pada graf, yakni pewarnaan simpul (vertex coloring), pewarnaan sisi (edge coloring), atau pewarnaan daerah (region coloring). Dalam tulisan ini akan dipaparkan pewarnaan simpul saja, mengingat graf yang dikenai pewarnaan sisi maupun daerah dapat direkayasa secara dual sehingga dapat dipandang sebagai suatu pewarnaan simpul. Sebagai contoh pewarnaan pada peta internasional merupakan pewarnaan daerah (region), yaitu setiap negara mendapatkan suatu warna yang berbeda dengan negara tetangganya. Negara-negara tersebut dapat dimodelkan menjadi simpul-simpul dan batas wilayah setiap 2 negara dapat dipandang sebagai sisi. Dengan demikian pewarnaan pada peta dapat dianggap sebagai pewarnaan simpul.

Suatu graf $\mathrm{G}$ dikatakan terwarnai bila setiap simpulnya diasosiasikan dengan suatu warna. Pewarnaan tersebut dikatakan teratur (properly colored) bila tidak ada dua simpul yang adjacent mendapatkan warna yang sama (Rosen, 2012). Dengan kata lain setiap dua simpul yang adjacent haruslah diberi warna yang berbeda, sebagaimana akan didefinisikan secara formal pada Definisi 1.

Definisi 1 Suatu pewarnaan teratur pada seluruh simpul anggota graf $G=(V, E)$ adalah pemetaan $\quad F: V \rightarrow \mathbb{N}$ dengan ketentuan simpul-simpul yang adjacent mendapatkan warna-warna yang berbeda di $\mathbb{N}$, artinya jika $\left\{v_{1}, v_{2}\right\} \in E$ maka $F\left(v_{1}\right) \neq F\left(v_{2}\right)$.

Memberi warna yang seluruhnya berbeda pada setiap simpul pada $\mathrm{G}$ merupakan hal yang tidak sulit, tetapi dalam penerapan pewarnaan graf pada masalah nyata hal tersebut tidak 
membawa manfaat berarti. Pewarnaan graf akan membawa manfaat dalam menyelesaikan masalah nyata bila banyaknya warna yang digunakan bersifat minimum, atau setidaknya mendekati minimum. Banyaknya warna minimum itulah yang disebut bilangan kromatik.

Bilangan kromatik dari suatu graf didefinisikan sebagai banyaknya warna minimum yang diperlukan untuk mewarnai suatu graf. Bilangan kromatik dari suatu graf $\mathrm{G}$ dilambangkan dengan $\chi(G)$, dalam hal ini $\chi$ merupakan huruf Yunani yaitu 'chi'. Graf $\mathrm{G}$ dikatakan kkromatik bila $\chi(G)=k$ untuk suatu $k \in \mathbb{N}$. Suatu kelas warna $V_{i}$, dengan $i=1,2, \ldots, k$ dari suatu pewarnaan $F$ memuat semua simpul yang sewarna. Kelas-kelas warna dari $F$ tersebut membentuk partisi dari $\mathrm{V}$ menjadi $\mathrm{k}$ buah subhimpunan yang saling asing. Pengertian mengenai kelas warna tersebut akan diperjelas melalui Contoh 1.

\section{Contoh 1}

Tentukan kelas-kelas warna graf $\mathrm{G}$ dengan $\chi(G)=3$ berdasarkan Gambar 1 .

Gambar 1 Graf planar G

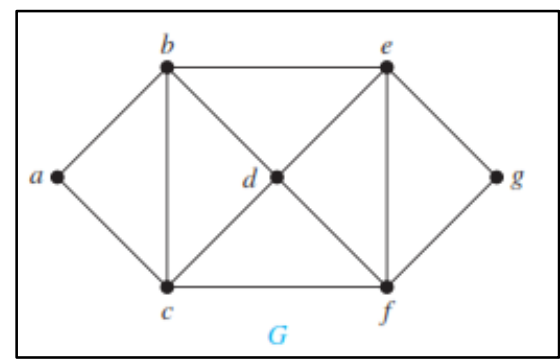

\section{$\underline{\text { Solusi }}$}

Dibentuk himpunan $\operatorname{simpul} V(G)=\{a, b, c, d, e, f, g\}$ dan himpunan warna $C=\{1,2,3\}, C \subset \mathbb{N}$. Pewarnaan akan dimulai dari simpul dengan derajat tertinggi, dalam hal ini kita bebas memilih satu dari antara simpul-simpul b, c, d, e, dan f sebagai pewarnaan awal. Dimulai dari simpul b diberi warna 1. Dapat ditemukan simpul derajat tertinggi yang tidak adjacent dengan simpul b, yakni simpul f, sehingga simpul f pun mendapatkan warna 1. Berikutnya simpul c diberi warna 2, demikian pula simpul e. Karena simpul d adjacent dengan simpul-simpul yang berwarna 1 dan 2 maka simpul d diberi warna 3. Simpul a dan g juga dapat diberi warna 3. Dengan demikian kelas-kelas warna graf $\mathrm{G}$ adalah

$$
\begin{gathered}
V_{1}=\{b, f\} \text { merupakan simpul }- \text { simpul berwarna } 1 . \\
V_{2}=\{c, e\} \text { merupakan simpul }- \text { simpul berwarna } 2 \\
V_{3}=\{a, d, g\} \text { merupakan simpul }- \text { simpul berwarna } 3 .
\end{gathered}
$$

Diperhatikan bahwa

$$
V_{1} \cup V_{2} \cup V_{3}=V
$$


Graf $\mathrm{G}$ yang sudah diwarnai ditampilkan pada Gambar 2.

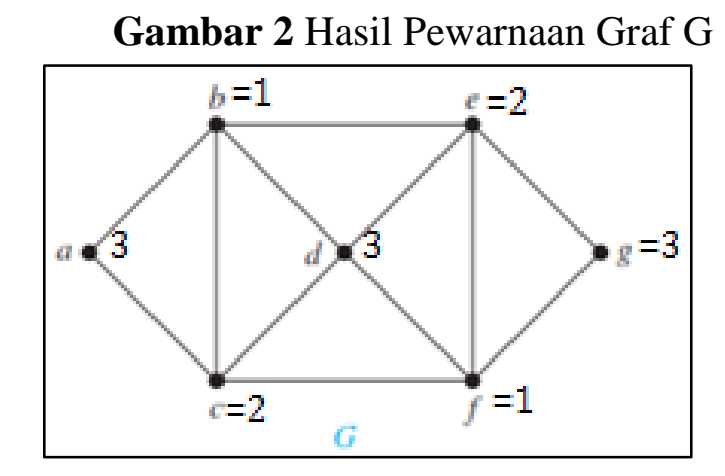

Dengan demikian Contoh 1 terselesaikan.

Karena setiap $V_{i}, i=1,2, \ldots, k$ memiliki warna unik yang berbeda-beda maka setiap dua kelas warna merupakan himpunan yang saling asing. Akibatnya, gabungan dari kelas-kelas warna graf G selalu sama dengan himpunan simpul G itu sendiri,

$$
\bigcup_{i=1}^{k} V_{i}=V_{1} \cup V_{2} \cup \ldots \cup V_{k}=V(G) \text {. }
$$

Sebagaimana disebutkan pada subbab pengenalan graf, nilai maksimum dari derajat simpul, $\Delta$, memegang peran penting dalam penentuan batas atas bilangan kromatik suatu graf, $\chi(G)$ sebagaimana telah dibuktikan dalam Stevens (2005). Selain batas atas, bilangan kromatik juga memiliki batas bawah. Batas bawah dari bilangan kromatik bergantung pada ukuran dari clique yang termuat di dalam graf tersebut.

Sifat-sifat bilangan kromatik yang dimaksud adalah

(1)Jika derajat terbesar simpul graf G adalah $\Delta$ maka $\chi(G) \leq \Delta+1$.

(2)Teorema Brooks, untuk setiap graf sederhana $\mathrm{G}$ yang connected, berlaku $\chi(G) \leq \Delta$, kecuali $\mathrm{G}$ graf lengkap atau graf lingkaran dengan $\mathrm{n}$ ganjil.

(3)Pada graf lengkap yang terdiri dari $\mathrm{n}$ buah vertex, derajat masing-masing simpulnya adalah $n-1$ sehingga $\chi(G)=\Delta+1=n-1+1=n$.

(4)Untuk setiap $\Delta$-reguler graf $\mathrm{G}$ dengan konektivitas 2 atau lebih, berlaku $\chi(G) \leq \Delta$. Jika konektivitasnya 1 maka $\chi(G)=\Delta$.

(5)Setiap graf bipartit dan graf pohon (tree) dapat diwarnai dengan 2 warna.

(6)Jika clique terbesar yang termuat di dalam $\mathrm{G}$ berukuran $\omega$ maka berlaku $\chi(G) \geq \omega$. Dalam hal ini $\omega$ disebut bilangan clique dari graf $\mathrm{G}$. 


\section{Algoritma Greedy}

Algoritma Greedy merupakan salah satu algoritma yang sering digunakan dalam melakukan pewarnaan graf. Dalam algoritma ini simpul-simpul dari graf yang akan diwarnai diurutkan terlebih dahulu menurut aturan tertentu. Salah satu aturan pengurutan simpul yang lazim digunakan adalah pengurutan berdasarkan derajat dari masing-masing simpul. Simpul dengan derajat terbesar menempati urutan pertama, dan simpul dengan derajat terkecil menempati urutan terakhir. Setelah simpul-simpul diurutkan, algoritma Greedy dapat dimulai dengan urutan kerja

1. Buatlah urutan pada warna-warna yang akan digunakan, sebagai contoh $\{1,2,3, \ldots, k\}$.

2. Ambil simpul urutan pertama dan berikan warna 1 .

3. Ambil simpul urutan berikutnya sesuai urutan simpul, beri warna dengan urutan terkecil yang belum diberikan kepada simpul lain yang adjacent terhadap simpul tersebut.

4. Ulangi langkah 3 hingga semua simpul terwarnai.

Contoh penerapan algoritma Greedy pada penjadwalan matakuliah disajikan pada Contoh 2.

\section{Contoh 2}

Pada Tabel 1 diberikan informasi incidence matakuliah v1,v2,..,v10 yang diselenggarakan oleh suatu program studi di suatu Universitas terhadap mahasiswa peserta dan dosen pengampunya. Digit biner 1 menunjukkan bahwa seorang atau sekelompok mahasiswa mengambil matakuliah tertentu atau seorang dosen ditugaskan untuk mengampu matakuliah tersebut. 
Tabel 1 Incidency 10 matakuliah terhadap mahasiswa dan dosen - Contoh 2

\begin{tabular}{|c|c|c|c|c|c|c|c|c|c|c|c|}
\hline \multirow{2}{*}{ No } & \multirow{2}{*}{$\begin{array}{c}\text { Mahasiswa } \\
\text { / Dosen }\end{array}$} & \multicolumn{10}{|c|}{ Matakuliah } \\
\hline & & v1 & v2 & v3 & v4 & v5 & v6 & v7 & v8 & v9 & v10 \\
\hline 1 & Mat 15 & 1 & & 1 & & & & & & & \\
\hline 2 & Mat 16 & & & & 1 & & & & & 1 & \\
\hline 3 & Mat 17 & & & & 1 & 1 & 1 & & & & 1 \\
\hline 4 & Mat 18 & & & & & & & & 1 & & \\
\hline 5 & Matsus 1 & & & & & & 1 & & 1 & & 1 \\
\hline 6 & Matsus 2 & 1 & & & & & & & & 1 & \\
\hline 7 & Matsus 3 & 1 & & 1 & & 1 & & & & & \\
\hline 8 & Matsus 4 & 1 & & & 1 & & 1 & & & & \\
\hline 9 & Eko 17A & & 1 & & & & & & & & \\
\hline 10 & Eko 17B & & & & & & & 1 & & & \\
\hline 11 & Dos A & 1 & 1 & & & & & & & & \\
\hline 12 & Dos B & & & 1 & 1 & & & & & & \\
\hline 13 & Dos C & & & & & 1 & 1 & & & & \\
\hline 14 & Dos D & & & & & & & 1 & 1 & & \\
\hline 15 & Dos $E$ & & & & & & & & & 1 & 1 \\
\hline
\end{tabular}

Tentukan

(a) Pewarnaan graf yang terdiri dari 10 simpul yaitu v1,v2,..,v10 berdasarkan Algoritma Greedy.

(b) Jadwal perkuliahan yang disarankan.

$\underline{\text { Solusi }}$

Berdasarkan tabel incidency pada Tabel 1, diperoleh matriks adjacency graf sebagaimana disajikan pada Tabel 2.

Tabel 2 Matriks adjacency graf Contoh 2.

\begin{tabular}{|c|c|c|c|c|c|c|c|c|c|c|}
\hline Adjacency & v1 & $\mathrm{v} 2$ & v3 & v4 & v5 & v6 & v7 & v8 & v9 & $\mathrm{v} 10$ \\
\hline v1 & 0 & 1 & 1 & 1 & 1 & 1 & 0 & 0 & 1 & 0 \\
\hline v2 & 1 & 0 & 0 & 0 & 0 & 0 & 0 & 0 & 0 & 0 \\
\hline v3 & 1 & 0 & 0 & 1 & 1 & 0 & 0 & 0 & 0 & 0 \\
\hline v4 & 1 & 0 & 1 & 0 & 1 & 1 & 0 & 0 & 1 & 0 \\
\hline v5 & 1 & 0 & 1 & 1 & 0 & 1 & 0 & 0 & 0 & 0 \\
\hline v6 & 1 & 0 & 0 & 1 & 1 & 0 & 0 & 1 & 0 & 1 \\
\hline v7 & 0 & 0 & 0 & 0 & 0 & 0 & 0 & 1 & 0 & 0 \\
\hline v8 & 0 & 0 & 0 & 0 & 0 & 1 & 1 & 0 & 0 & 0 \\
\hline v9 & 1 & 0 & 0 & 1 & 0 & 0 & 0 & 0 & 0 & 1 \\
\hline v10 & 0 & 0 & 0 & 0 & 0 & 1 & 0 & 0 & 1 & 0 \\
\hline
\end{tabular}


Dengan bantuan MsExcel diperoleh urutan simpul dari derajat terbesar hingga terkecil sebagaimana ditampilkan pada Tabel 3.

Tabel 3 Urutan simpul berdasarkan derajatnya.

\begin{tabular}{|l|l|l|l|l|l|l|l|l|l|l|}
\hline Simpul & v1 & v4 & v6 & v5 & v3 & v9 & v8 & v10 & v2 & v7 \\
\hline Derajat & 6 & 5 & 5 & 4 & 3 & 3 & 2 & 2 & 1 & 1 \\
\hline
\end{tabular}

Dengan menggunakan bantuan www.graphonline.ru diperoleh graf yang memiliki 10 simpul, mewakili matakuliah v1,v2,..,v10 yang ditampilkan pada Gambar 2.

\section{Gambar 2 Graf Matakuliah Contoh 2}

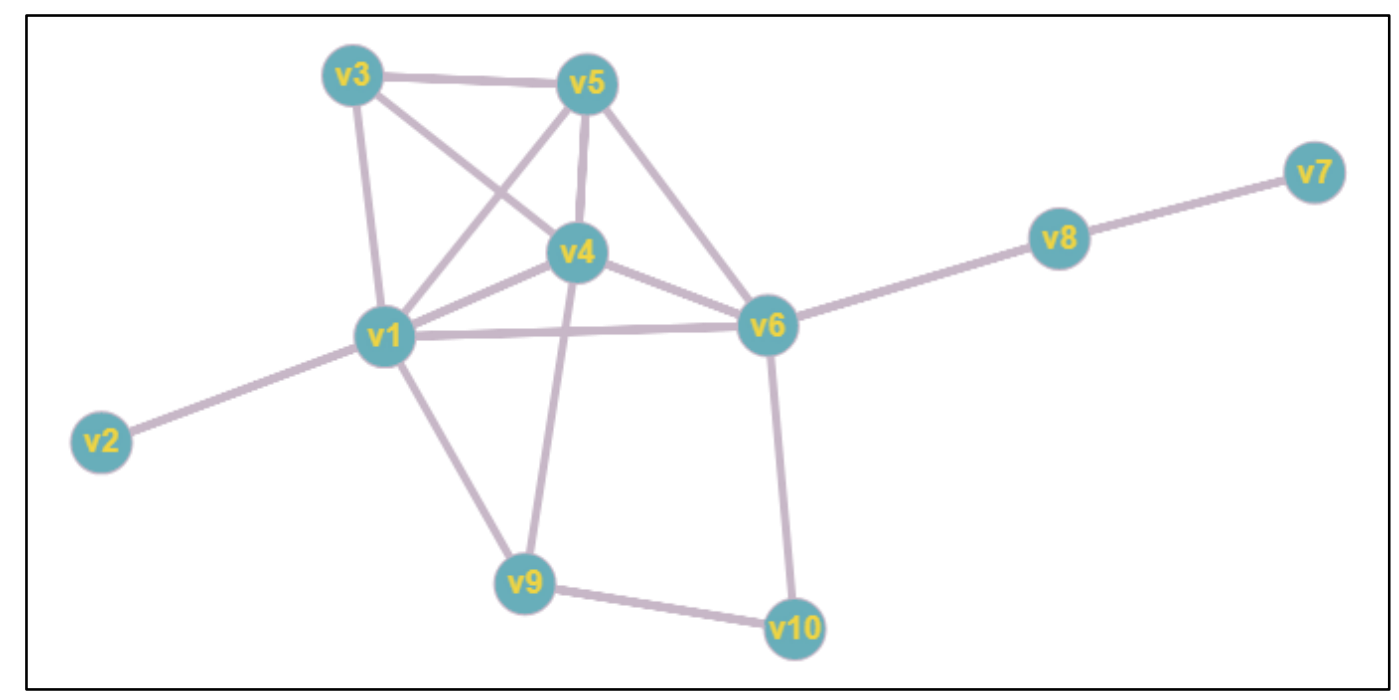

Karena derajat terbesar dari simpul-simpul pada graf tersebut adalah 6, maka berdasarkan Teorema Brooks pewarnaan dapat dilakukan dengan bilangan kromatik tidak lebih dari 6, yaitu

$$
\chi(G) \leq 6 .
$$

Oleh karena itu dibentuk himpunan warna $C=\{1,2,3,4,5,6\}$.

Diperhatikan pula bahwa pada Gambar 2 ditemukan subgraf $G 1=\{v 1, v 4, v 5, v 6\}$ yang bersifat lengkap, dan tidak dapat ditemukan subgraf lengkap lain yang berukuran lebih besar dari G1, artinya G1 ini merupakan clique terbesar yang terdiri dari 4 simpul. Dengan kata lain bilangan clique dari graf pada Gambar 2 adalah 4, sehingga bilangan kromatiknya sekurangkurangnya adalah 4. Diperoleh

$$
4 \leq \chi(G) \leq 6
$$

Pewarnaan dengan algoritma Greedy dimulai dari simpul berderajat terbesar yaitu v1, diberi warna 1. Selanjutnya diperhatikan v6 adjacent dengan v1 sehingga v6 diberi warna 2. Simpul v4 adjacent dengan v1 maupun v6, sehingga v4 diberi warna 3. Simpul v5 adjacent dengan 3 simpul sebelumnya sehingga diberi warna 4. Simpul v3 adjacent dengan v1(warna 1), v6(warna 2), dan v5(warna 4), tetapi tidak adjacent dengan simpul v4(warna 3), sehingga v3 diberi warna 3. Demikian seterusnya hingga dihasilkan pewarnaan lengkap yang ditampilkan pada Tabel 4. 
Tabel 4 Pewarnaan Greedy Contoh 2

\begin{tabular}{|l|l|l|l|l|l|l|l|l|l|l|}
\hline Simpul & v1 & v6 & V4 & v5 & v3 & v9 & v8 & v10 & v2 & v7 \\
\hline Derajat & 6 & 5 & 5 & 4 & 3 & 3 & 2 & 2 & 1 & 1 \\
\hline Warna & 1 & 2 & 3 & 4 & 2 & 2 & 1 & 1 & 2 & 2 \\
\hline
\end{tabular}

Graf yang telah selesai diwarnai disajikan pada Gambar 3, dengan demikian soal (a) telah terselesaikan.

Gambar 3 Graf terwarnai secara Greedy - Contoh 2

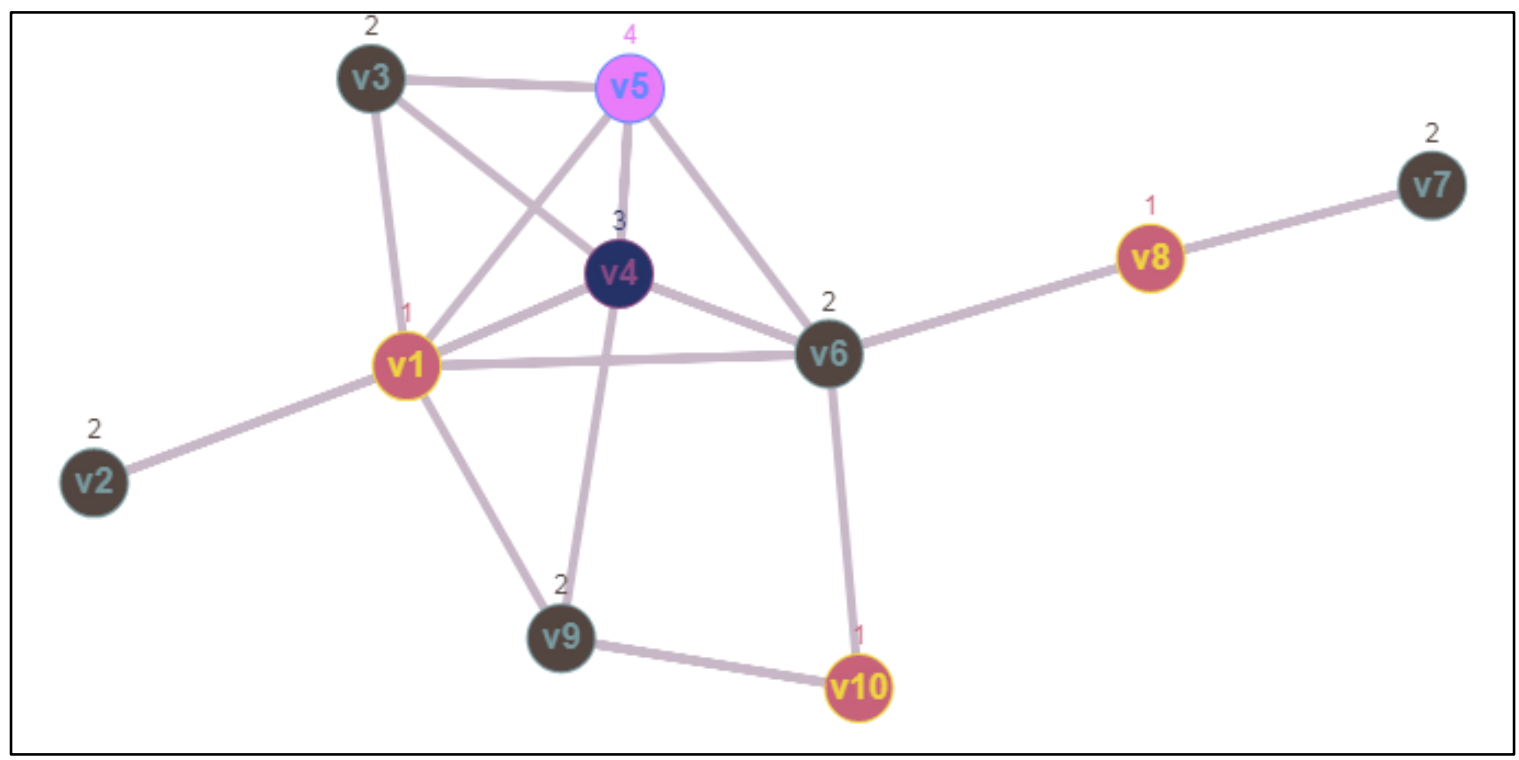

Selanjutnya akan dibentuk jadwal perkuliahan yang disarankan. Diasumsikan setiap matakuliah memiliki kredit masing-masing 2 sks. Diasumsikan pula jam kuliah yang dikehendaki adalah pagi (08.00) hingga siang (12.00). Karena banyaknya warna yang digunakan hanya 4, maka akan digunakan 4 buah slot waktu di hari Senin dan Selasa, pagi hingga siang sebagaimana ditampilkan pada Tabel 5. Dengan demikian soal (b) terselesaikan.

Tabel 5 Jadwal yang disarankan - Contoh 2.

\begin{tabular}{|l|l|l|}
\hline Hari / Jam & Senin & Selasa \\
\hline $08.00-10.00$ & $\mathrm{v} 1, \mathrm{v} 8, \mathrm{v} 10$ & $\mathrm{v} 4$ \\
\hline $10.00-12.00$ & $\mathrm{v} 6, \mathrm{v} 3, \mathrm{v} 9, \mathrm{v} 2, \mathrm{v} 7$ & $\mathrm{v} 5$ \\
\hline
\end{tabular}

Bila ada matakuliah yang memiliki kredit 3 sks, jadwal berikutnya dari matakuliah tersebut dapat dialokasikan pada hari Rabu atau Kamis dengan jam kuliah sesuai jadwal di hari Senin atau Selasa. Sebagai contoh misalkan matakuliah v1 memiliki kredit 3 sks. Karena v1 sudah dijadwalkan di hari senin selama 2 jam dari jam 8 pagi hingga jam 10, maka 1 jam berikutnya dapat dijadwalkan di hari Rabu jam 8 pagi hingga jam 9 pagi. 


\section{Algoritma Welsh-Powell}

Algoritma ini dipublikasikan pertama kali oleh Welsh dan Powell pada tahun 1967 (Gross, 1996). Algoritma Welsh-Powell memiliki kesamaan dengan algoritma Greedy yaitu simpul-simpul graf haruslah diurutkan terlebih dahulu, biasanya berdasarkan derajatnya, yaitu dari derajat tertinggi sampai derajat terendah. Hanya ada 1 perbedaan langkah pada algoritma ini, yaitu pewarnaan simpul setelah simpul pertama. Langkah selengkapnya dari algoritma Welsh-Powell adalah

1. Buatlah urutan pada warna-warna yang akan digunakan, sebagai contoh $\{1,2,3, \ldots, k\}$.

2. Ambil simpul urutan pertama dan berikan warna 1.

3. Berikan warna yang sama kepada simpul urutan berikutnya yang tidak adjacent pada simpul sebelumnya. Bila hal itu tidak dapat dilakukan, gunakan warna berikutnya kepada simpul yang adjacent dengan simpul sebelumnya tetapi memiliki derajat tertinggi.

4. Ulangi langkah 3 hingga semua simpul terwarnai.

Kita tinjau kembali graf yang terkait dengan soal Contoh 2.

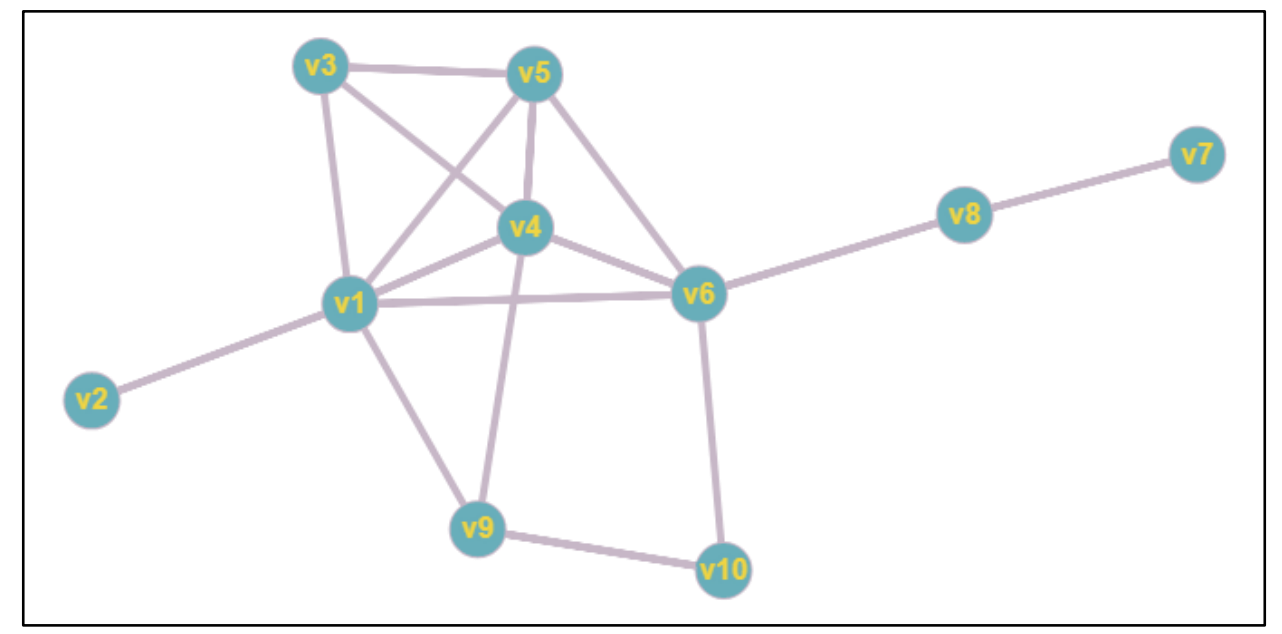

Urutan derajat simpul pada graf tersebut adalah

\begin{tabular}{|l|l|l|l|l|l|l|l|l|l|l|}
\hline Simpul & v1 & v6 & V4 & v5 & v3 & v9 & v8 & v10 & v2 & v7 \\
\hline Derajat & 6 & 5 & 5 & 4 & 3 & 3 & 2 & 2 & 1 & 1 \\
\hline
\end{tabular}

Pewarnaan Welsh Powell pada graf tersebut dimulai dengan pemberian warna 1 pada v1, kemudian v10, demikian pula dengan v8. Selanjutnya warna 2 diberikan kepada v6, v3, v9, v2, dan v7. Akhirnya v4 diberi warna 3 dan v5 diberi warna 4. Hasil pewarnaan algoritma ini sama dengan algoritma Greedy, tetapi memiliki urutan kerja yang lebih sederhana bila dikerjakan secara manual, ditampilkan pada Tabel 6. 
Tabel 6 Perbandingan Hasil Pewarnaan Welsh-Powell dengan Greedy.

\begin{tabular}{|l|l|l|l|l|l|l|l|l|l|l|}
\hline Simpul & v1 & V6 & V4 & v5 & v3 & v9 & v8 & v10 & v2 & v7 \\
\hline Derajat & 6 & 5 & 5 & 4 & 3 & 3 & 2 & 2 & 1 & 1 \\
\hline Warna (Greedy) & 1 & 2 & 3 & 4 & 2 & 2 & 1 & 1 & 2 & 2 \\
\hline $\begin{array}{l}\text { Warna } \\
\text { (Welsh Powell) }\end{array}$ & 1 & 2 & 3 & 4 & 2 & 2 & 1 & 1 & 2 & 2 \\
\hline
\end{tabular}

Komparasi waktu kerja akan lebih akurat bila kedua algoritma ini dibandingkan secara komputasi, artinya perlu dibentuk program komputer menggunakan algoritma Greedy dan Welsh Powell, kemudian dibandingkan waktu kerjanya (running time comparation).

\section{KESIMPULAN DAN SARAN}

Berdasarkan pemaparan teori-teori dan contoh-contoh pada subbab sebelumnya disimpulkan

1. Jika suatu graf $\mathrm{G}$ memiliki bilangan clique $\omega$ dan derajat terbesar dari simpul-simpulnya $\Delta$, maka bilangan kromatik $\chi$ graf tersebut memenuhi

$$
\omega \leq \chi(G) \leq \Delta .
$$

2. Baik algoritma Greedy maupun Welsh-Powell memberikan hasil akhir pewarnaan yang identik, tetapi berbeda urutan kerjanya.

3. Penggunaan bantuan graf online melalui www.graphonline.ru dapat mempercepat proses pemodelan jadwal matakuliah menjadi graf berdasarkan matriks adjacency-nya.

Penelitian ini dapat dilanjutkan dengan pemodelan dan penyelesaian masalah jadwal matakuliah nyata pada suatu program studi di suatu universitas menggunakan algoritma Greedy atau Welsh Powell. Mengingat masalah penjadwalan nyata melibatkan puluhan bahkan ratusan matakuliah, sehingga terbentuk graf dengan puluhan sampai ratusan simpul, disarankan untuk membangun sebuah program komputer untuk menyelesaikan proses pewarnaan graf secara lebih cepat.

\section{DAFTAR PUSTAKA}

Ariani, D. (2011). Optimasi Penjadwalan Mata Kuliah di Jurusan Teknik Informatika Menggunakan Particle Swam Optimization. Retrieved 12 30, 2018, from https://www.researchgate.net: https://www.researchgate.net/publication/277171205_OPTIMASI_PENJADWALAN _MATA_KULIAH_DI_JURUSAN_TEKNIK_INFORMATIKA_PENS_DENGAN_ MENGGUNAKAN_ALGORITMA_PARTICLE_SWARM_OPTIMIZATION_PSO/

Astuti, S. (2011). Penyusunan Jadwal Ujian Matakuliah Dengan Algoritma Pewarnaan Graf Welch Powell. Jurnal Dian Vol. 11. 
Burke, E. K. (2002). A New Adaptive Heuristic Framework for Examination Timetabling Problems. Working Group on Automated Timetabling.

Chauduri, A., \& De, K. (2010). Fuzzy Genetic Heuristic for University Course Timetable Problem . International Journal of Advances in Soft Computing and its Applications .

Euler, L. (1741). Euler Solution to the Konigsberg Bridge Problem. Retrieved 12 30, 2018, from www.maa.org: https://www.maa.org/press/periodicals/convergence/leonardeulers-solution-to-the-konigsberg-bridge-problem

Rosen, K. H. (2012). Discrete Mathematics and Its Applications, 7th Edition. New York: McGraw Hill.

Setiawan, H. (2015). Implementasi Algoritma Kunang-Kunang Untuk Penjadwalan Mata Kuliah di Universitas Ma Chung. Jurnal Buana Informatika.

Stevens, B. (2005). Graph Coloring and Their Properties. Retrieved 12 30, 2018, from https://www.whitman.edu:

https://www.whitman.edu/Documents/Academics/Mathematics/stevens.pdf

Werra, D. d. (1984). An Introduction to Timetabling. European Journal of Operation Research. 